\title{
Evidence of Late Quaternary seismicity from Yunam Tso, Lahaul and Spiti, NW Himalaya, India
}

\author{
Archna Bohra $^{1, *}$, B S Kotlia ${ }^{2}$, Amzad H Laskar $^{3}$ and M G Yadava ${ }^{3}$ \\ ${ }^{1}$ Centre for Glaciology, Wadia Institute of Himalayan Geology, Dehra Dun 248 001, India. \\ ${ }^{2}$ Department of Geology, Kumaun University, Nainital 263 002, India. \\ ${ }^{3}$ Geosciences Division, Physical Research Laboratary, Navrangpura, Ahmedabad 380 009, India. \\ *Corresponding author. e-mail: archna.bohra@gmail.com
}

A relict fluvio-lacustrine sediment of an $8 \mathrm{~m}$ thick section exposed at Kilang Sarai along Yunam river, near Baralacha La shows presence of cycloids or pseudonodules, ball and pillow structures, flame-like and pocket structures, sand dyke injections, bed dislocation/faulting and flow folds. Within this section four deformed levels of soft sediment structures have been identified which were dated ca. $25 \mathrm{ka}$ BP at level 1 ( $\sim 0.4 \mathrm{~m}$ from the modern river level $(\mathrm{mrl}), 20.1 \mathrm{ka} B P$ at level $2(\sim 1.8 \mathrm{~m} \mathrm{mrl}), 17.7 \mathrm{ka}$ $\mathrm{BP}$ at level $3(\sim 2.56 \mathrm{~m} \mathrm{mrl})$ and $12.2 \mathrm{ka} \mathrm{BP}$ at level $4(\sim 4.25 \mathrm{~m} \mathrm{mrl}))$. Detailed study of these soft sediment structures allow us to demonstrate that deformation level 3 is not related to seismic trigger, but remaining three deformation levels (1,2 and 4) are ascribed to seismic origin. From compilation of earlier palaeoseismological studies using soft sediment deformational structures (SSDS) in the palaeolake deposits in the adjoining area, suggest that the deformational events identified in the present study are regional in nature and thus tectonic process plays an important role in the evolution of landform in the Spiti region.

\section{Introduction}

Study of the liquefaction phenomenon and features caused due to earthquakes is vital for earthquake hazard assessment and palaeoseismology. The soft sedimentary deformation structures (SSDS) or seismites in the lakes are the direct expression of the seismic activity associated with faults and are generated under the same regional or local stress field that originated in the fault slip (Rodríguez-Pascua et al. 2000). Therefore, these structures can be used to reconstruct the past seismic history of a region beyond the historical records (Allen and Banks 1972; Jayangondaperumal et al. 2008; Mugnier et al. 2011).
The various deformation structures attributed to seismic activity include ball-and-pillow (Potter and Pettijohn 1963), pseudo-nodules or cycloids (Hempton and Dewey 1983), pinchand-swell bedding and lenticular boudins, pocketand-pillar structures (Postma 1983), flame-like structures (Visher and Cunningham 1981) and sedimentary dykes. As the development of these structures are triggered by seismic shaking, they are interpreted as seismites (Sims 1975; Marcos et al. 1996; Rosseti 1999; Ken-Tor et al. 2001; Greb and Dever 2002; Bowman et al. 2004; Jayangondaperumal and Thakur 2008; Perucca et al. 2009; Phartiyal and Sharma 2009; Wang et al. 2011).

Keywords. Quaternary; fluvio-lacustrine sediments; Baralacha La (La = Pass); Yunam Tso (Tso = river); soft sediment structures and seismites. 


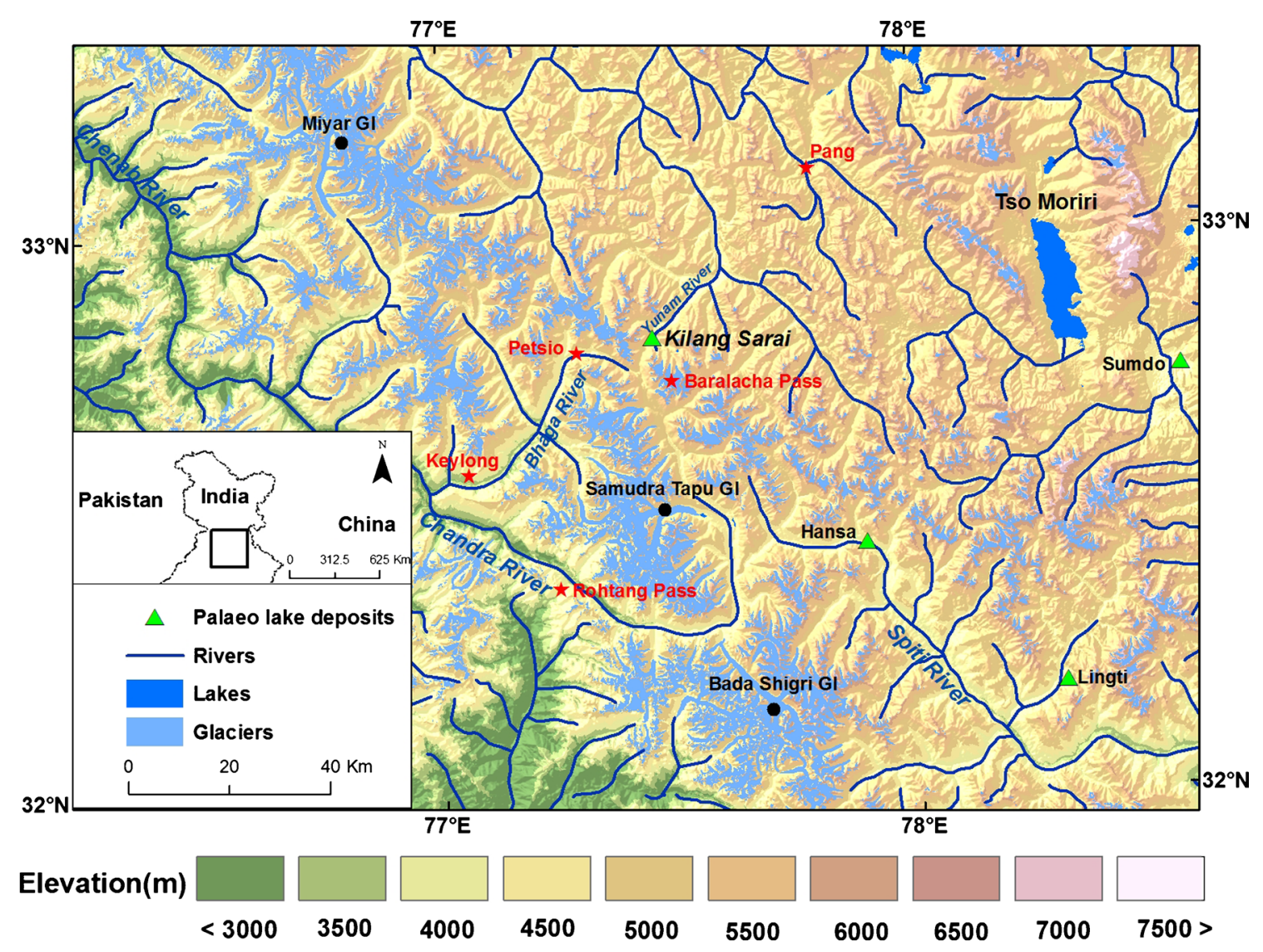

Figure 1. Distribution of modern lakes, Kilang Sarai palaeolake and surrounding glaciers as observed in SRTM.

The potential sites for palaeoseismic studies are young lakes and lake sediments (Sims 1973, 1975; Allen 1975; Sieh 1978). It has been suggested that a majority of the Himalayan lakes were formed due to the tectonic triggered landslides (Burbank and Johnson 1982; Agrawal et al. 1989) in Ladakh (figure 1) (Burgisser et al. 1982; Fort et al. 1989; Kotlia et al. 1997a), Central Himalaya (Sastry et al. 1970; Juyal et al. 2004) and Kumaun Himalaya (Kotlia and Rawat 2004; Kotlia et al. 1997b, 2010). In view of this it is reasonable that episodic tectonic activity in the vicinity of the lakes is likely to be registered in the form of deformation in the planner beds. This is amply demonstrated in the Lahaul region which is traversed by major faults like Baralacha Fault, Sarchu Fault, Spiti Fault and Kaurik-Chango Fault (figures 2 and 3). It has been suggested that the activity along these faults has resulted in the development of SSDS which were used for reconstructing the past seisimc activity by various researchers (Bhargava 1990; Singh and Jain 2007; Phartiyal et al. 2009a, b; Hintersberger et al. 2010; Anoop et al. 2012).

In order to understand the Quaternary tectonic activity of the Yunam Tso basin, Sarchu block, we use SSDS preserved in relict proglacial lake sediments that are located on the hanging wall of Baralacha Fault in the upper reaches of Yunam valley at Kilang Sarai (Tethys Himalaya) (figures 2 and 3). The reason being, it is located in the north of the Pir Panjal ranges which are considered to have undergone active tectonic uplift from Miocene to Late Cenozoic times (Bhargava 1990) and there is no data on the palaeoseismic activity from this region. Hence the present study fills the gap of understanding of the Late Quaternary seismicity from the western part of the Spiti valley.

In this paper, we describe the type and nature of deformational structures preserved in the Kilang Sarai lake sediments and mechanism of their formation. Then we compare the evidence with other lakes in Upper Spiti region.

\section{Study area}

The study area (figures 1 and 3 ) is located above the tree line $\left(3000 \mathrm{~m}\right.$ asl, $\left.31^{\circ}-33^{\circ} \mathrm{E} ; 77^{\circ}-79^{\circ} \mathrm{S}\right)$, comprising of two NW-SE trending normal faults, the Chandra Fault and Sarchu Fault (Bhargava 1990). A number of geomorphological features, e.g., development of gorges (figure 4a) and canyons, 


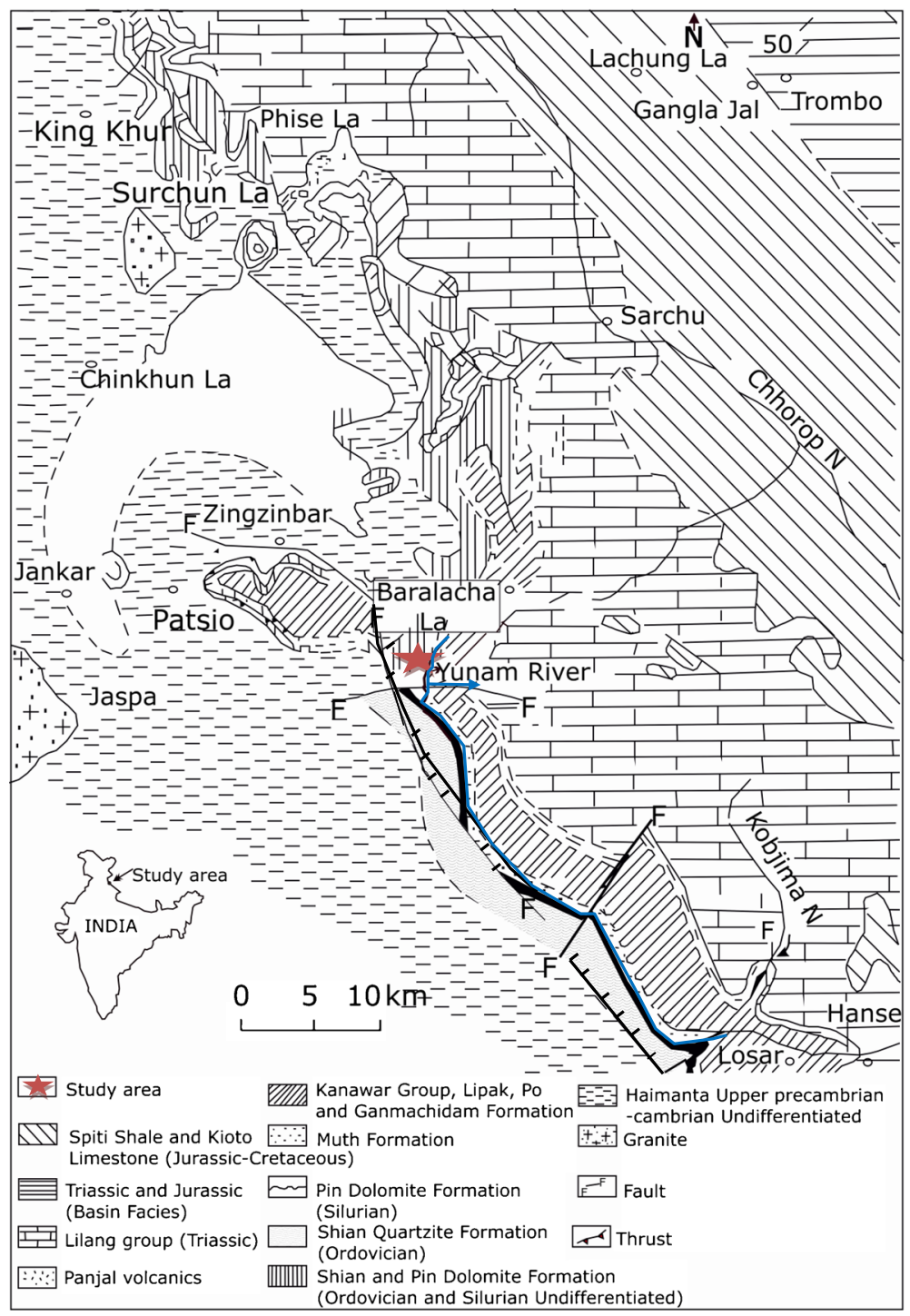

Figure 2. Location and geological map of the study area with location of transverse faults (after Bagati and Suresh 1991).

meandering of Yunam Tso (figure 4b), formation of river terraces, triangular fault facets and entrenched meanders along the Yunam river indicate the terrain is tectonically active. The Baralacha La represents the watersheds of three rivers: the Yunam flows down to the NNE, crossing perpendicularly the main Himalayan structures, and joining the Lingti and Tsarap rivers in the Sarchu Plain (figure 3). The direction of two rivers, the Bhaga towards west and Chandra towards SE of Pass is controlled by a concentration of Himalayan folds and thrusts (figure 2). The geological study reveals a great number of SW vergent thrust and folds near Baralacha. Descending the Chandra valley to the SE, the Baralacha thrust is replaced by SW vergent folds of the Chandra Tal flexure. The NW extent of Baralacha Fault shows normal sense of motion (Robyr et al. 2006). Our field studies also suggest that the Baralacha Fault is parallel to the Chandra Fault. The Baralacha La Thrust and the Chandra Tal flexure correspond to an attenuation of the deformation in the front of the Nyimaling-Tsarap Nappe (Epard and Steck 2004). The Yunam Tso river originates from the Baralacha La, flow through a number of parallel diminutive faults (figure 2). The lithology is dominated by quartzites, shales, sandstone, limestone and metasedimentary rocks belonging to Palaeozoic and Mesozoic periods (Bhargava and Bassi 1998). Activities along these faults are manifested by displacement of the country rocks. At places, the damming of the Yunam Tso river by debris are seen. Considering that the terrain lies in the rain shadow zone, due to the orographic barrier of the High Himalaya in the south, the geomorphic processes are dominated by frost action, ice flow deposits and debris fan emanating from the relict cirque glaciers. 


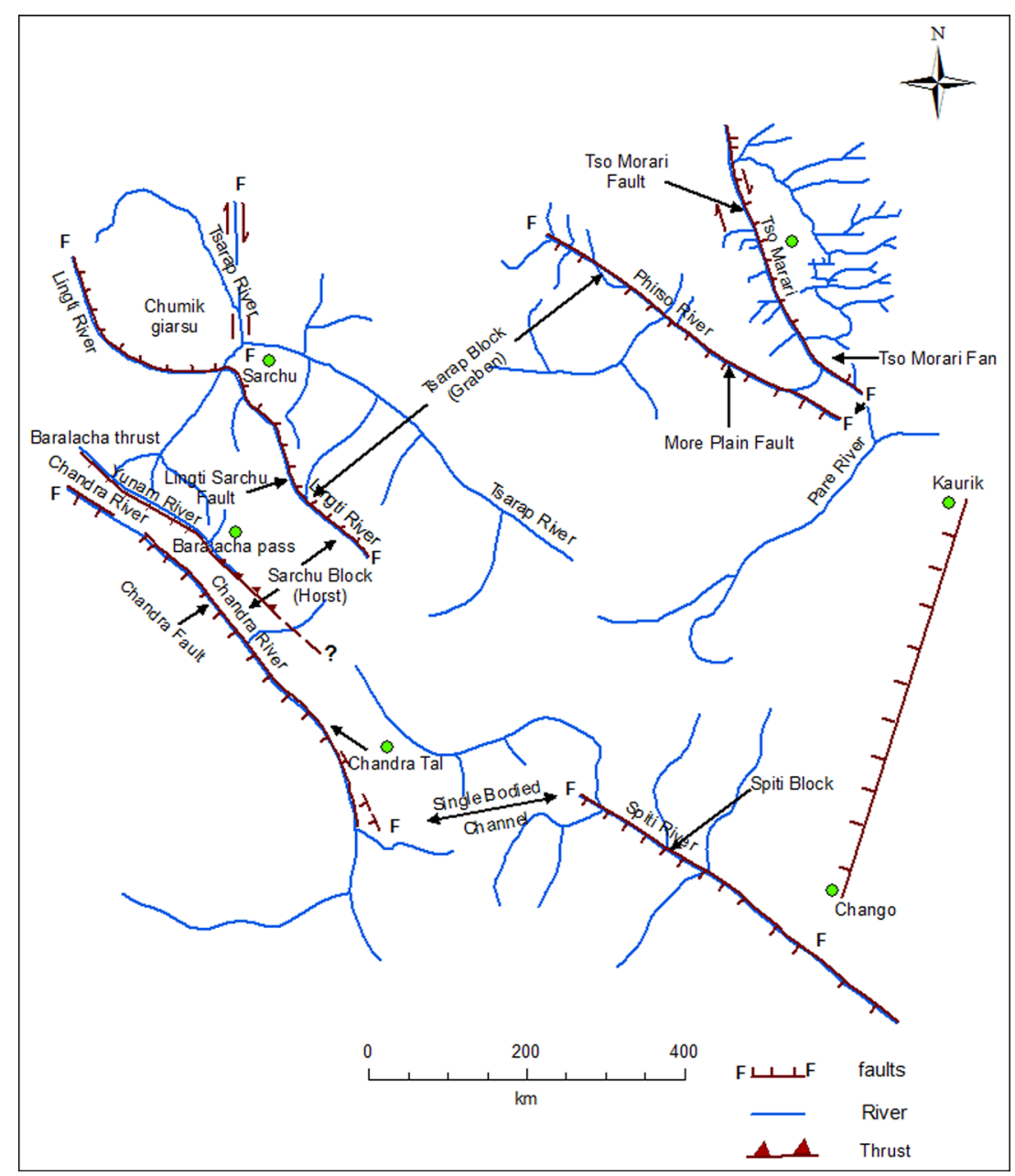

Figure 3. A simplified regional structural map showing major fault system in the Spiti valley (after Bhargava 1990).

In the present study, the relict lake section at Kilang Sarai $\left(77^{\circ} 27^{\prime} \mathrm{E}\right.$; $32^{\circ} 49^{\prime} \mathrm{N}$, altitude $4573 \mathrm{~m}$ asl) (figures $4 \mathrm{~b}$ and 5) in the Yunam palaeolake basin has been investigated for palaeosesimic studies. The relict lake deposits extend $\sim 11 \mathrm{~km}$ up along the Yunam Tso river up to Bharatpur and are dominated by greyish coloured clayey-silt and sandy horizons.

\subsection{Palaeolake stratigraphy}

The studied section lies $25 \mathrm{~m}$ above the Yunam Tso river bed at Kilang Sarai. The size of the Kilang Sarai basin is $11 \mathrm{~km}$ that extends in E-W direction. The basin is filled with a thick $8 \mathrm{~m}$ of fluvio-lacustrine laminated section exposed along the Yunam Tso river (figure $5 \mathrm{a}$ and $\mathrm{b}$ ). Based on the sediment texture, the deposits in the basin can be divided into three major units, viz., (i) the lower glacial outwash, is the lowest exposed unit of $0.4 \mathrm{~m}$ thick that contains angular to sub-round lithoclasts, referred to as unit-1, (ii) the middle laminated lake sediments of $5.6 \mathrm{~m}$ thick unit sits above the unit-1. It is composed mainly of laminated (2-3 $\mathrm{m}$ thick) light grey to dark grey varves, referred to as unit-2, and (iii) the laminated unit sequence finally terminates with the deposition of well sorted, rounded to subrounded gravels of $0.4 \mathrm{~m}$ thick at the topmost part of the exposed section, referred to as the upper river born gravel unit-3 (figure 5).

\section{Chronology}

In order to ascertain the timing of lake formation and to constrain the chronology of deformation events, conventional radiocarbon method (using Liquid Scintillation counter, LKB 1220 Quantulus) on the three organic layers of the lake sediment was performed at Physical Research Laboratory, Ahmedabad. For conventional dates, bulk sediment samples $(300-600 \mathrm{gm})$ were treated with $10 \% \mathrm{HCl}$ for 10-12 hours to remove carbonates, if any. The samples were washed with distilled water to attain $\mathrm{pH}=7$, dried and combusted in a quartz tube 

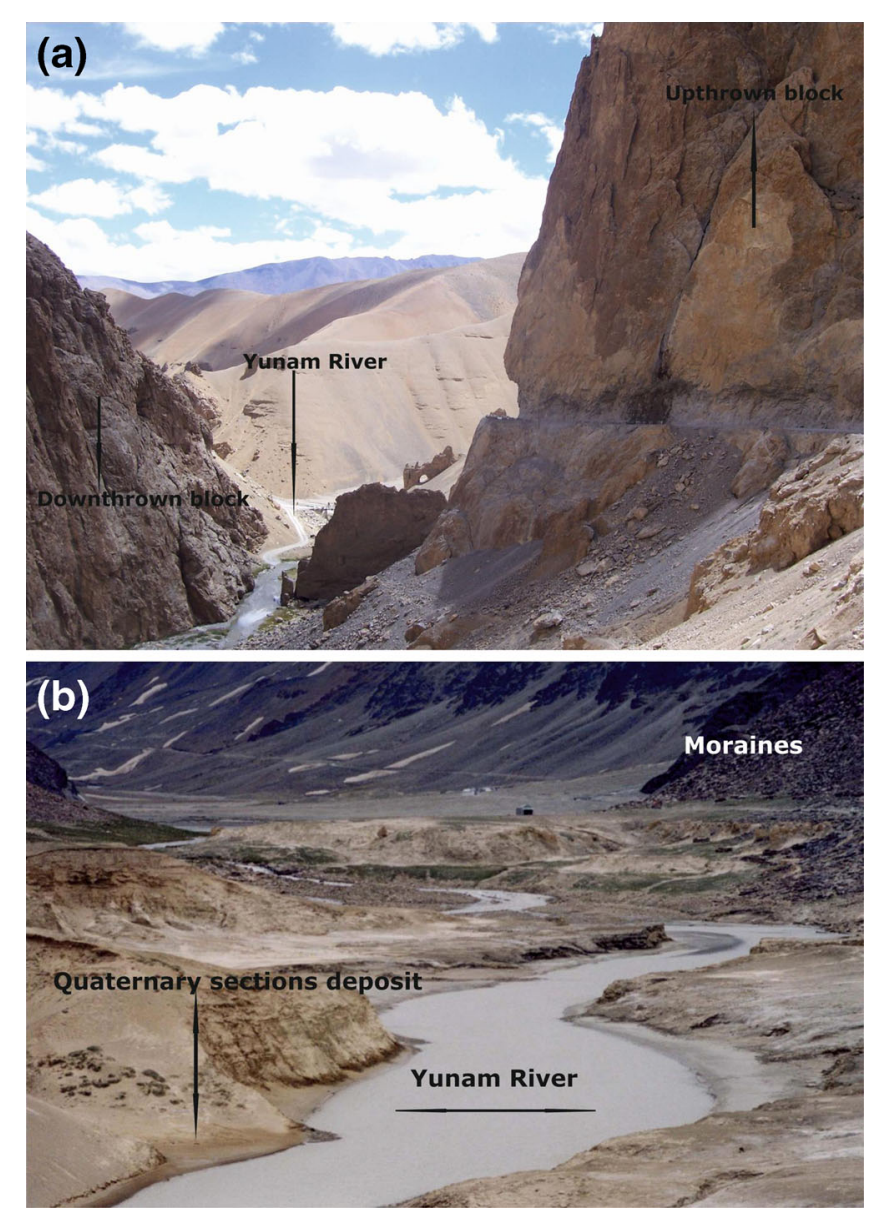

Figure 4. Tectonic evidences from the study area: (a) formation of deep Gorge at Bharatpur village and (b) meandering of Yunam Tso.

at $\sim 900^{\circ} \mathrm{C}$ under continuous flow of pure oxygen. The $\mathrm{CO}_{2}$ produced was converted into benzene, the activity of which was counted in LKB 1220 Quantulus (for details, see Yadava and Ramesh 1999).

A total of three samples (AB-2, AB-20 and AB$40)$ are dated which gave an age of $25.3 \mathrm{ka} \mathrm{BP}$ (AB2 at depth $0.44 \mathrm{~m}$ ), $26.5 \mathrm{ka} \mathrm{BP}$ (AB-20 at depth $2.58 \mathrm{~m}$ ) and $12.2 \mathrm{ka} \mathrm{BP}$ (AB-40 at depth $4.41 \mathrm{~m}$ ) (table 1). Age at $2.58 \mathrm{~m}$ depth (sample AB-20) was not taken into consideration for data interpretation as it gave an overexerted age. The details of the sample location and soft sedimentary deformational levels are mentioned in the subsequent subheading under the SSDS (4). To constrain the timing of the four deformation events, the age model is constructed based on two samples (AB2 and AB-40) ages. On the basis of these ages, observed sedimentation rate $31 \mathrm{~cm} / 1000$ yr was obtained and these ages are referred as modelled age. Assuming a constant sedimentation rate the observed ages (obtained or modelled) were kept with respect to height (Kilang Sarai section) using the following formula $y=-0.299 x+8.0245$, where $x=$ age and $y=$ height (table 1 , figure 5b). According to the observed age in table 1 , the assumed sedimentation rates have been found in considerable values (the observed height and expected height with \% error is also shown). The calculated modelled age is shown in italics and actual ages are shown in bold numbers (figure 5b).

\section{Soft sediment deformation structures (SSDS)}

A thick fluivo-lacustrine sediment sequence shows four SSDS levels, deformation level 1 through 4 that are observed between 0.4 and $4.4 \mathrm{~m}$ marks of an $8 \mathrm{~m}$ exposed section along the Yunam Tso river. The SSDS in this succession include water-escape structures, load structures, hydroplastic structures and kink/small scale faults. The textural and structural properties of SSDS at different levels are given in table 2. Since the deformed sediments are showing weakly developed organic horizons, we collected bulk sediments to quantify the timing of these deformation levels and thus timing of lake deposits. The radiometric ages of these bulk sediments and age-depth modelled ages are given in table 1 .

\subsection{Deformational level 1}

It is the lowermost deformation level-1 and located immediately above the glacial outwash unit- 1 at $0.4 \mathrm{~m}$ height from the modern river level (figure 5). The deformation shows simple convolution structures with $0.2 \mathrm{~m}$ thickness (figure $6 \mathrm{a}$ ). The convolutions are folded with varying amplitude that are developed in the clay layers filled with the sand. The inclination of axial plane of the convolution varies NW-SE from vertical to near horizontal. These features are laterally traced up to several tens of meters in the exposed section (figure $6 \mathrm{~b}$ ). One sediment sample AB-2 collected within this level gave a radiometric age of $25.3 \pm 0.35 \mathrm{ka} \mathrm{BP}$.

\subsection{Deformational level 2}

The deformational level 2 lies at $1.8 \mathrm{~m}$ from the base, is dominated by pseudo-nodules occuring at the interface between sand and clay units (figure 6c). In addition, few sand nodules are attached to the parent sand bed that shows the deformation is more pronounced in the coarser sandy layer rather than the clay layer. This may be due to greater susceptibility of sand layer to liquefaction as compared to the clay layer. These structures look similar to the load structures. The convoluted structures at places show development of recumbent folds (figure $6 \mathrm{~d}$ and e). 


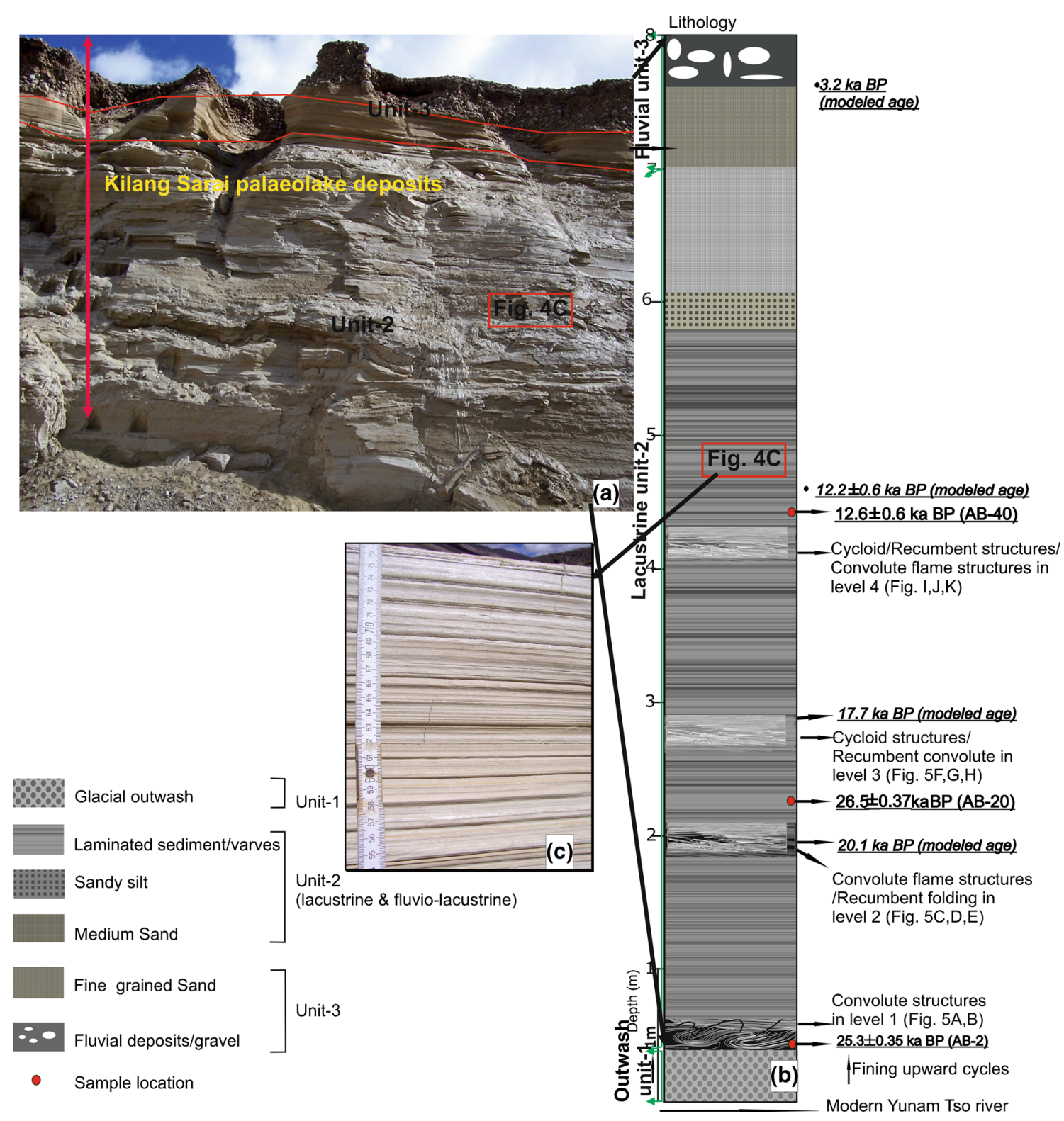

Figure 5. (a) Kilang Sarai lacustrine section, (b) Litholog of Kilang Sarai section (marked with soft sediment deformational structures from level 1 to level 4) with position of deformational structures and radiocarbon dates (modelled ages are shown in italics). (c) Close view of the laminated sediments.

Table 1. Radiocarbon ages of the samples from Kilang Sarai section.

\begin{tabular}{lccccc}
\hline Sl. no. & $\begin{array}{c}\text { Sample } \\
\text { name }\end{array}$ & $\begin{array}{c}\text { Age } \\
(\text { ka BP })\end{array}$ & $\begin{array}{c}\text { Observed } \\
(\text { depth })\end{array}$ & $\begin{array}{c}\text { Estimated } \\
(\text { depth })\end{array}$ & \% error \\
\hline 1 & AB-40 & 12.2 & 4.25 & 4.37 & $( \pm 2.82)$ \\
2 & AB-22 & 17.7 & 2.58 & 2.73 & $( \pm 5.81)$ \\
3 & AB-7 & 20.1 & 1.8 & 2.00 & $( \pm 11.09)$ \\
4 & AB-2 & 25.0 & 0.4 & 0.54 & $( \pm 35.00)$ \\
\hline
\end{tabular}

The axial plane of these recumbent folds is along NW-SE direction. The strike direction of these folds is parallel with regional Himalayan structural grains. AB-20 sediment sample within this level yielded a radiometric age of $26.5 \pm 0.37 \mathrm{ka}$ BP.

\subsection{Deformational level 3}

The stratigraphic sequence in the deformation level 3 is demarcated by presence of drop stone structures, 10-13 cm in thickness with varying shapes (i.e., eye and angular shapes) (figure 6f). The 


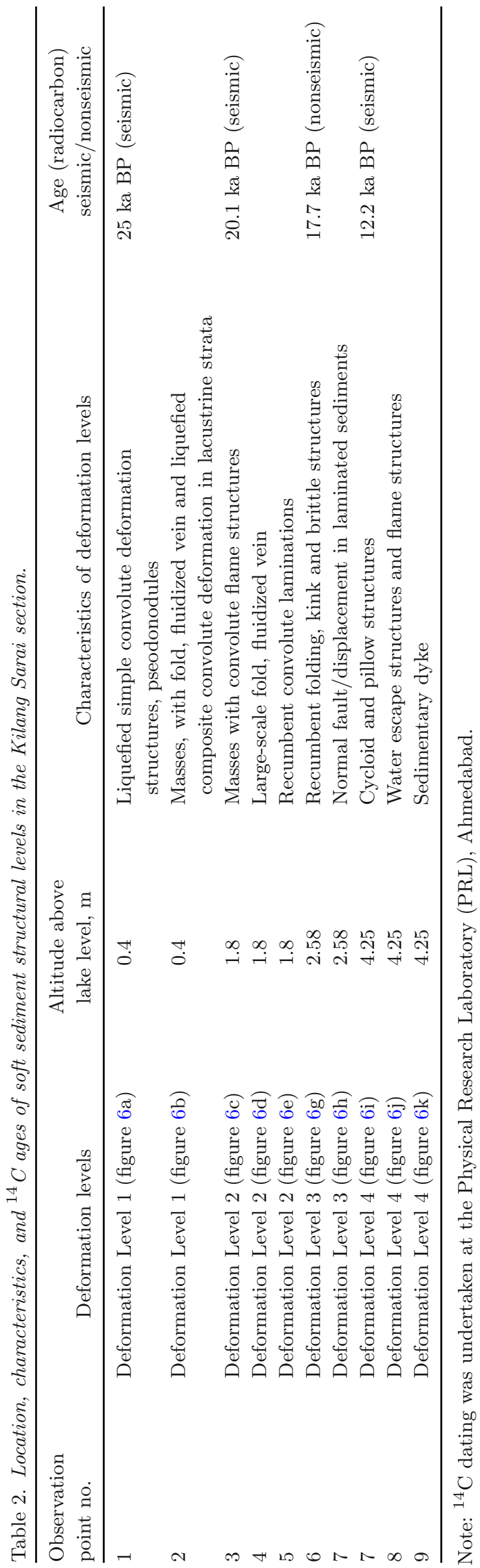

deformation level 3 shows dominance of recumbent folds which vary in thickness from 3 to $15 \mathrm{~cm}$ and occur at $2.58 \mathrm{~m}$ above the deformational level 2 (figure $6 \mathrm{~h}$ ). The simple recumbent folds consist of single and multiple hinges in the silty-clay and laminated clayey sediments. The axial plane of these folds varies from $2-3 \mathrm{~m}$ and shapes of hinges vary from circular to sharp crested, and at places, are faulted. The folds are $3-12 \mathrm{~cm}$ in thickness and upper fold limbs persist consistently, whereas the lower limbs converge into kink structures/small scale faults. The brittle reverse fault strikes $125^{\circ}$ in NE-SW $\left(125^{\circ}\right)$ direction (figure $6 \mathrm{~h}$ ). The fault plane appears slightly concave upward and ends in clayey-silt layers. The faulting has ruptured and displaced $4-5 \mathrm{~cm}$ laminated light grey clayey-silt by $3-5 \mathrm{~cm}$ (figure $6 \mathrm{~g}$ and $\mathrm{h}$ ).

\subsection{Deformational level 4}

The deformed sediment at level 4 occurs at $4.25 \mathrm{~m}$ above the deformational level 3. The deformed sediments are dominated by sands and gravels showing ball-and-pillow shaped structures/cycloid structures (figure 6i). The ball-and-pillow structures are commonly identified in the fine sand units with relatively undisturbed flat tops and bulbous, pillowed base. The flat or slightly wavy base marks a gradational contact with underlying horizontal beds. Towards upper part of the deformation level 4 the convolute similar to flame structures have been observed (figure 6j). Two dykes are observed at same exposure. Dykes extend upwards more than $5 \mathrm{~m}$ from its liquefied sandy unit and form an upward conical structure or intrusion dykes (figure 6k). The structures of the dykes show that these are sedimentary in origin; as it thinned out upward and did not cut through the upper strata (figure 6k). These dykes are synchronously formed along with soft sedimentary structures. One sample AB-40 collected for radiometric age within this level gave an age of $12.6 \pm 0.6 \mathrm{ka} \mathrm{BP}$.

\section{Interpretation of soft sediment structures and lake deposits}

The lacustrine deposits consist of laminated couplets (figure $5 \mathrm{c}$ ), which seem to be the annual varves. Considering their climatic implications and location of the study area, we consider such deposits anomalous in the specific sense that they reflect depositional processes distinctly different from rhythmic annual deposition of suspended sediments. The varve deposition belongs to the proglacial lake environments. The thin, finegrained winter portion of each couplet is typically $<1 \mathrm{~mm}$ thick and ranges from clay to silt. The 

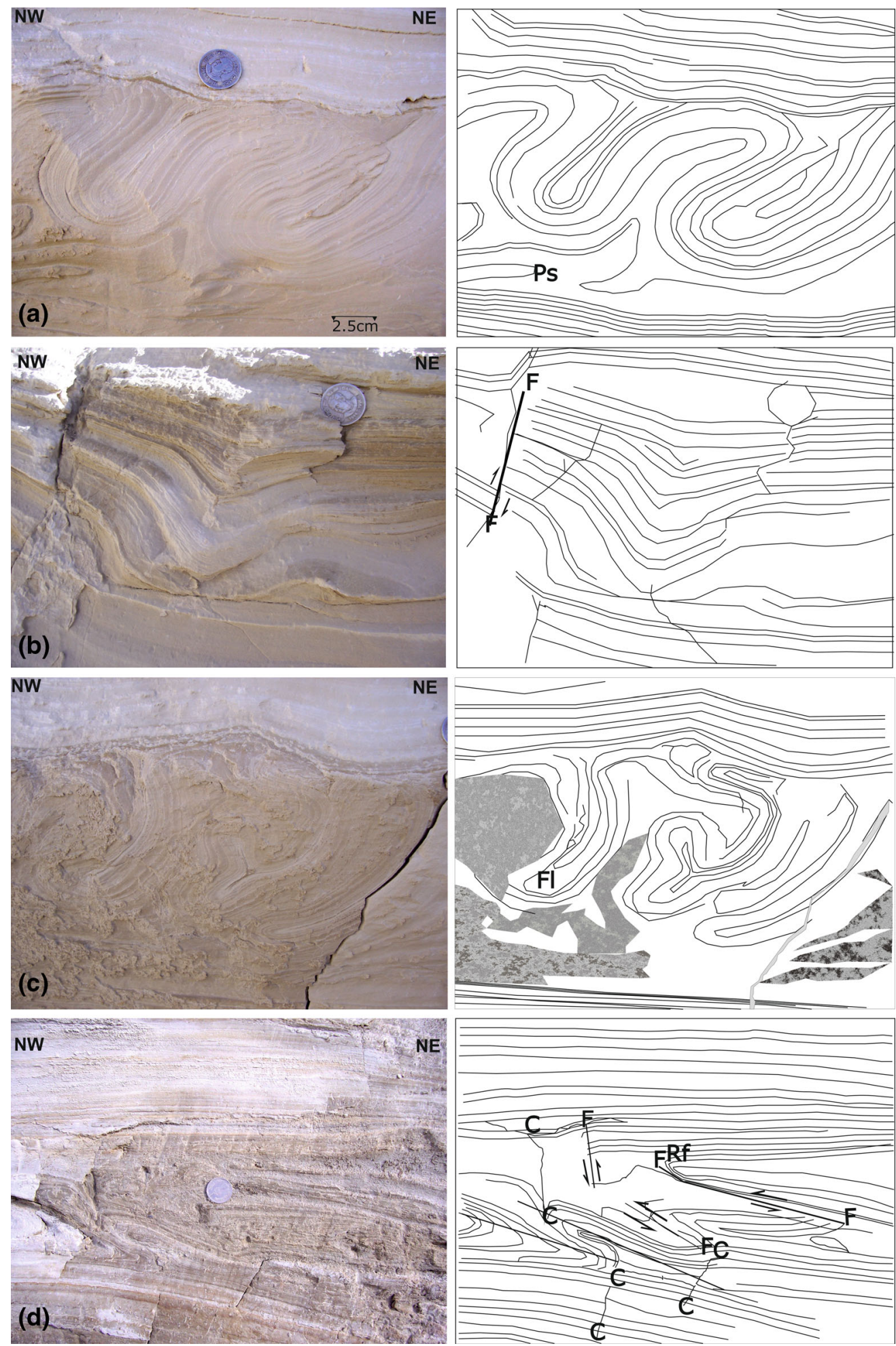

Figure 6. Field photograph and extract sketch of the Kilang Sarai section showing soft sediment deformational structures. (a) Simple convolute structures and pseudonodules (Ps) at level 1. (b) Composite convolute structures in the level 1 (India rupee for scale, diameter $=2.5 \mathrm{~cm}$ ) (for location, see figure 5a). (c) Diapiric/convolute flame structures $(\mathrm{Fl})$ developed within the laminated sediments overlain by silty sand in level 2. (d) Recumbent folding in the laminae, associated with high angular faults (F) in level 2 (for location, see figure 4a). (e) Recumbent convolute structures (Rc) in the laminated clay and sand in level 2. (f) Dropstone in the level 3. (g) A level of brown humic clayey sand was liquefied and injected in the underlying injected sand showing brittle normal fault in level 3 (for location, see figure 4a). (h) Recumbent folding and composite convolute (Cc) in level 3. (i) Cycloid structures developed in the sand engulfed within clayey sediments. Recumbent structures (Rc) and hydroplastic mixing (Hp) of sand and clays in level 4 (for location, see figure 4a). (j) Convolute flame structures in the clays overlain by sands. Flames $(\mathrm{Fl})$ in clay are seen rising upwards in level 4 . (k) Folded bed giving rise to dyke/diapir like structures at the top (showing a $6 \mathrm{~m}$ sand dyke rest overlying silty clay sediment) in level 4 . 

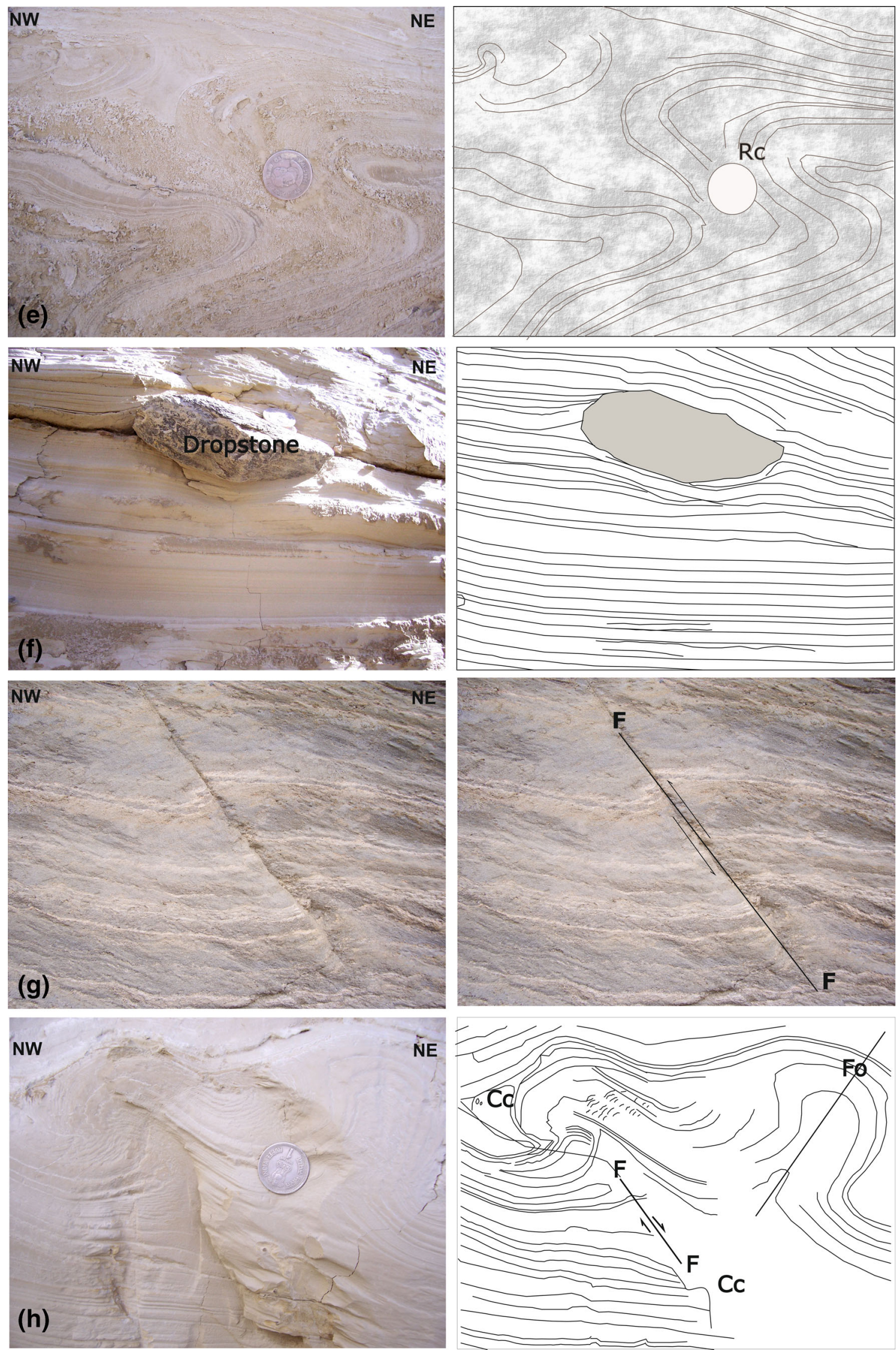

Figure 6. (Continued.) 

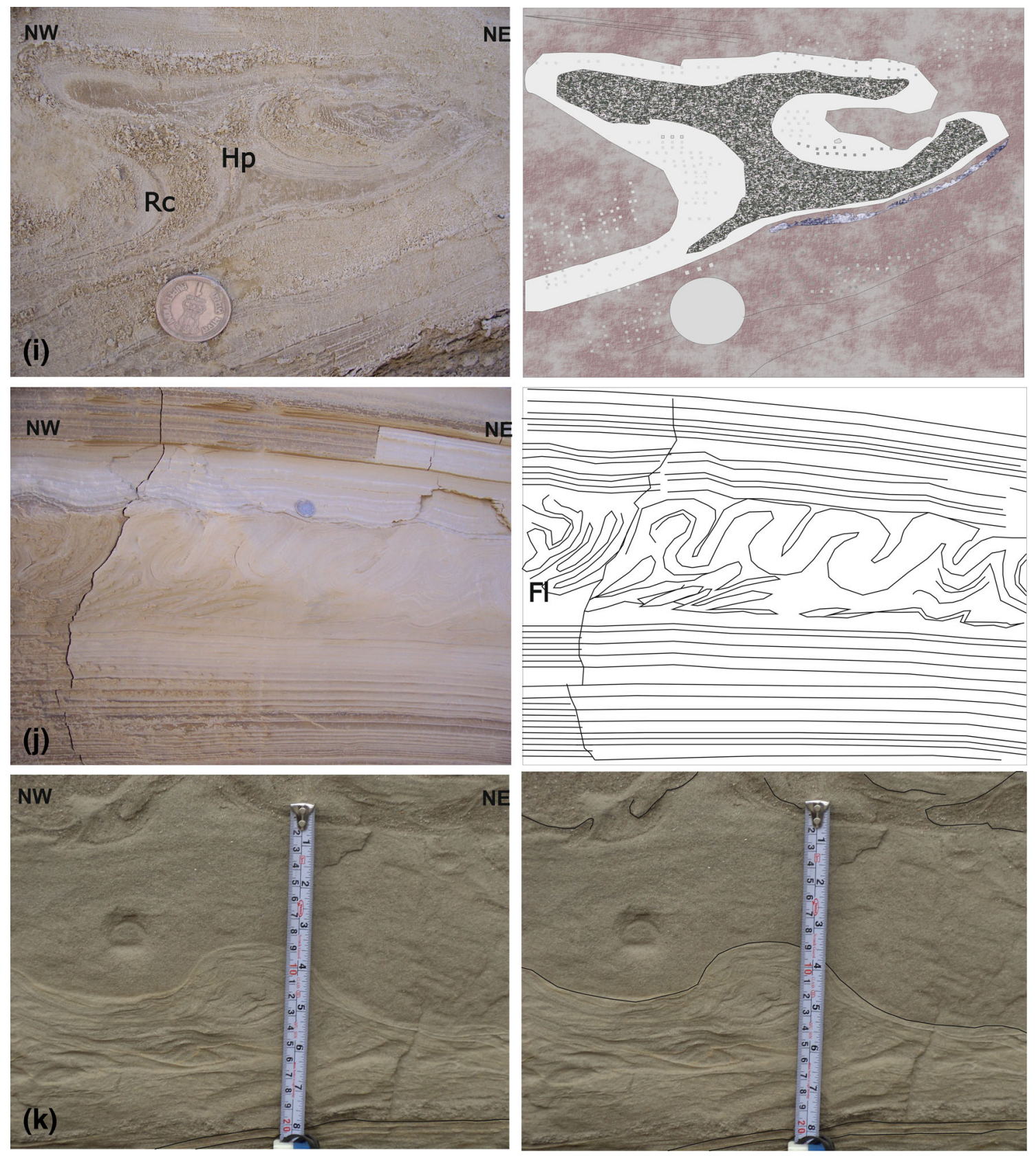

Figure 6. (Continued.)

summer layers are more variable, with thickness of $1 \mathrm{~mm}$ to several $\mathrm{cm}$ and with grain sizes ranging from silt to coarse sand. The typical summer deposits exhibit weak intra-seasonal laminations, with a gradual textural transition to the winter deposit.

The radiometric age integrated with modelled age based on age-depth model of the lacustrine sediments suggest that the Yunam lake sedimentation began around $25.3 \mathrm{ka} \mathrm{BP}$ and continued until around 3.2 ka BP (figure 5). There were some episodic movements of water reflected by presence of silt or sand in the upper unit (unit-3). Finally coarse-grained gravel (conglomerate) sat on the top of the lacustrine section showing the lake breaching at $\sim 3$ ka BP (figure $5 \mathrm{~b}$ ). The whole laminated section is bounded by glaciated outwash (i.e., unit1) at the bottom and river born gravel at the top (i.e., unit-3).

The origin of convolutions (figure $6 \mathrm{a}, \mathrm{b}$ ) in lacustrine deposit, can be related to elastic-plastic response of sediment to shear-stress caused due to back and forth movement of water (Hibsch et al. 1997; Rodríguez-Pascua et al. 2000; RodríguezLópez et al. 2007) and movement of water can be either by dynamic stress during the earthquake 
activity (Khatri et al. 1978). The recumbent folds are developed in the cohesive laminated clay and silt, overlain by sands (Rosseti 1999; figure 6d and e). It has been suggested that these structures were produced by high magnitude seismic shocks at sediment water interphase (Van Loon 2002). The presence of dropstone in deformational level 3 implies its deposition either by landslide activity or by glacial transport. The reverse faulting is observed along NE-SW direction which is just opposite to the direction of active faults (i.e., Baralacha Fault, Sarchu Fault, Spiti Fault and Kaurik Chango Fault) and hence the origin of this structure is due to sudden cryogenic dumpling due to glacial activity in the region, hence the formation of SSDS is controlled by nonseismic in origin. The formation of ball-and-pillow structures in the deformational level 4 (figure 6i), structures are facilitated by the presence of texturally heterogeneous over and underlying sediment (Kelling and Walton 1957; Kuenen 1958; Potter and Pettijohn 1963; Hempton and Dewey 1983). In the present case, underlying sediment is dominated by coarse sand which is susceptible to liquefaction compared to the overlying medium sand.

The development of the flames (figure 6j) is due to drawing up of the fine grained sediment by current drag (Kuenen and Menrad 1952) or shear stresses and reverse density loading (Mills 1983). This suggests that the fluidization process was triggered by the seismic shock waves produced by the earthquakes.

The observed SSDS correlated with seismites and validated in the present study on the basis of field evidence, previous studies together with the important criteria as given by Sims (1975) are as follows:

- the SSDS are found between sand and clay layers and are invariably separated by the undeformed subhorizontal beds,

- these horizons are continuous and can be traced for more than $1.5 \mathrm{~km}$,

- these are small scale internal structures within deformed zones that suggest liquefaction,

- these are restricted to single stratigraphic intervals and;

- there is absence of detectable influence by slopes, slope failure, or other sedimentological, biological or deformational process.

\section{Discussion}

Our study indicates that SSDS in Kilang Sarai palaeolake caused by liquefaction and fluidization formed in noncohesive sediments is mostly caused by earthquakes (Obermeier 1996a). The presence of pseudonodules and complex folded flame like structure ascribe intense deformation caused possibly by higher intensity earthquakes (Mohindra and Bagati 1996), while over-steepened or flame-like structures are responsible for low intensity earthquakes. Presence of angular to subrounded outwash gravel indicates their deposition under flashy condition. Considering that the terrain had undergone significant glacial activity during the Late Quaternary (Pant et al. 2005), we suggest that unit-1 deposits represent outwash of earlier phase of deglaciation when debris-laden water transported the morainic sediments from the upper valleys during the glacial recession phase. The unit-2 conform laminated light grey to dark grey sequence represent proglacial lake environment. Whereas unit-3 of fine sediments at the uppermost part (figure 5) represent the winnowing phase of the flood (Campbell and Evan 1990). The uppermost rounded to sub-round gravel (2$15 \mathrm{~cm}$ in thickness) indicate abrupt increase in the discharge causing the breaching of the lake around 3.2 ka BP (figure 5a).

In general, the liquefaction features form away from the meizoseismal zone and thus it is considered as secondary off fault features (Obermeier 1996a; Jayangondaperumal and Thakur 2008). SSDS and the formation of clastic dikes in the Himalaya have recently been related to in situ deformation during earthquake shaking (Jayangondaperumal et al. 2008; Mugnier et al. 2011; Rajendran and Rajendran 2011) and are referred to as seismites.

The SSDS observed with the Kilang Sarai palaeolake can be associated with seismic event because, tectonically

(i) the Spiti region is active as proved by a recent earthquake (1975 AD) of $6.8 \mathrm{Ms}$ (Singh et al. 1975; Khatri et al. 1978);

(ii) liquefiable lacustrine sediments are present;

(iii) slope failures are lacking;

(iv) movement of convolute structures are observed in both directions;

(v) SSDS occur in a wide lateral extent for several tens of meter within the Yunam palaeolake basin and bounded by parallel and undeformed beds (10-30 cm in thickness) are possibly seismically triggered (Allen 1986; Obermeier 1996b).

This finding strongly corroborates Obermeier's (1996a, b) conclusion about the large variations in the abundance of liquefaction-induced features within a local area. The absence of SSDS in upper part (above level 4, see figure 5a) in the section is possibly due to density heterogeneity caused by increased sedimentation (Anoop et al. 2012). 
Instrumental records over the last five decades suggest that during 1975 the terrain experienced an earthquake of magnitude 6.8 (Singh et al. 1975) which was associated with the NS trending Kaurik-Chango Fault (figure 3) (Singh et al. 1975) and seismic activity dating back to late Pleistocene (Banerjee et al. 1997). Our study region lies near Sarchu Fault, Kaurik-Chango Fault towards east and Chandra Fault towards its SE (figure 2b). These faults responsible for development of the horst and graben structures (figure $2 \mathrm{~b}$ ) in the study region imply the region is tectonically active. It is interesting to note that the study area lies $\sim 200 \mathrm{~km}$ from Kaurik-Chango Fault, which might have affected the study area during high magnitude seismic activity. It is well supported by the fact that the occurrence of an earthquake at a particular place can be responsible for a stress transfer up to $\sim 230 \mathrm{~km}$ of its surrounding and may cause disruption in the form of generation of liquefaction (cf. Jayangondaperumal and Thakur 2008). The earlier study based on luminescence dating and few radiocarbon ages suggested that the terrain was tectonically active during the Late Quaternary and majority of lakes were formed during Quaternary period as a result of damming of the rivers due to the tectonic activity or glacial outburst.

Therefore, it is reasonable to suggest that the formation of these lakes was structurally controlled and that the SSDS preserved in the lakes were of same period can be correlated with the tectonic activity associated with major faults in the respective regions (Burgisser et al. 1982; Burbank and Johnson 1982; Agrawal et al. 1989; Fort et al. 1989; Kotlia et al. 1997a).

Figure 7 provides compilation of chronology of all lake deposits in the adjoining valleys, together with present dated Yunam lake deposits in the Spiti valley. Based on the compilation of existing records the lake formation in Spiti Himalaya started around $90 \mathrm{ka}$ and continued older than $4.0 \mathrm{ka}$. The seismic activity reported from relict lake sequences from Spiti region by various researchers is between 90 and 6.1 ka.

For example, Singh and Jain (2007), based on luminescence ages obtained for a continuous lake sequence near Sumdo village suggested that the terrain was tectonically active 90-26 ka ago with a recurrence interval of $\sim 10 \mathrm{ka}$. Phartiyal et al. (2009a), based on their observations in Lingti and Hansa lakes suggested two sesmic events around 12 and $7 \mathrm{ka}$, respectively. More recently, Hintersberger et al. (2010) identified NW-SE and NS striking normal faults in the Lingti valley responsible for the development of SSDS structures which are optically dated to $\sim 40 \mathrm{ka}$. Anoop et al. (2012), based on their study in the Mane relict lake sediments identified four seismic events which are radiocarbon dated to ca. $7.8,7.4,6.5$ and $6.1 \mathrm{ka}$ respectively.

The younger seismic event from Kilang Sarai dated to $12.2 \mathrm{ka} \mathrm{BP}$ (level 4) is in conformity with the observation made by Phartiyal et al. (2009a) in Lingti lake sediment (figure 7). Similarly, another event of $20.1 \mathrm{ka}$ BP (SSDS level 2) can be correlated with the regional seismic activity reported from Lingti palaeolake section in upper Spiti which gave an age of $21.3 \pm 1.1 \mathrm{ka}$ (Hintersberger et al. 2010). SSDS level 4 corresponds to the seismic events reported from Sumdo laminated section from Spiti region that occured at $26 \pm 4.3 \mathrm{ka}$ (Singh and Jain 2007) (figure 7). The SSDS level 3 at 17.7 ka BP perhaps shows some cryogenic activity with preservance of drop stone and the opposite direction of the faults (figure $5 \mathrm{~F}, \mathrm{G}$ and $\mathrm{H}$ ) suggests that the post LGM warming seems to have taken place in our study area during this time span.

Thus, based on the chronology and age depth model we suggest that Yunam basin lake experienced three major seismic events that can be bracketed between 25 and $12 \mathrm{ka}$ BP during the existence of lake. The lowermost SSDS level 1 is dated to $25 \mathrm{ka} \mathrm{BP}$, level 2 corresponds to $20.1 \mathrm{ka} \mathrm{BP}$, level 3 dated to $17.7 \mathrm{ka} \mathrm{BP}$ and the uppermost layer level 4 dated to $12.2 \mathrm{ka} \mathrm{BP}$. The identified tectonic activities between 25 and $12 \mathrm{ka} \mathrm{BP}$ in the present study is in good agreement with previously dated tectonic events in the Spiti valley.

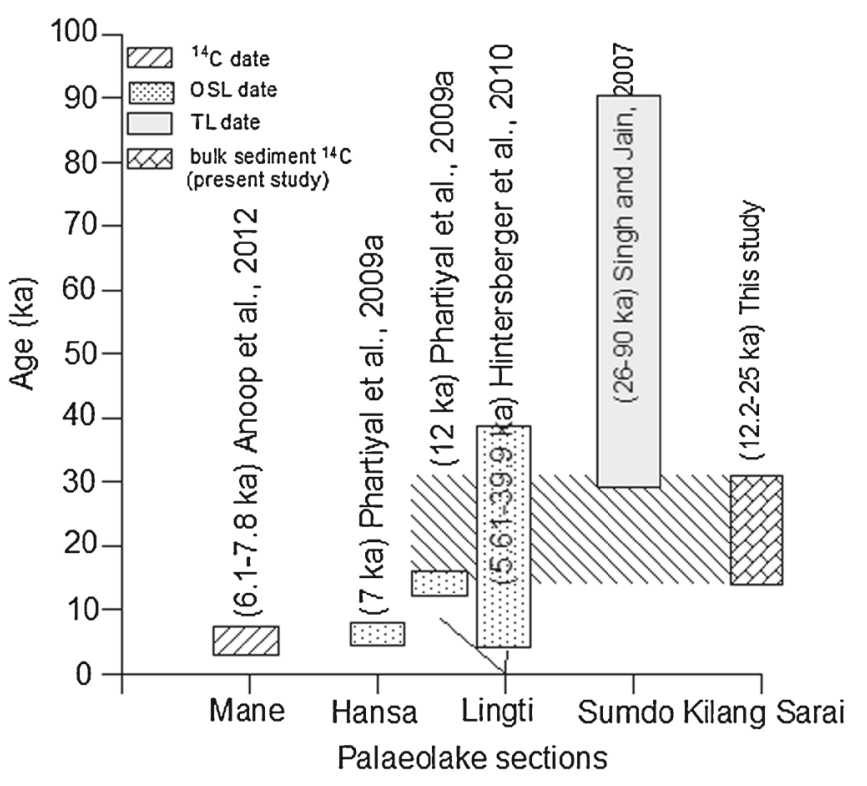

Figure 7. Space-time diagram showing previously dated palaeolake deposits containing SSDS together with present dated liquefied events from the Spiti valley region. The dated liquefied events in the present study is in harmony with the liquefied found in the Lingti and Sumdo Palaeolake deposits. 


\section{Conclusions}

Our observations enable us to draw the following conclusions.

- The geomorphic setting and textural attributes of the lake sediment suggest that the sedimentation occurred in a proglacial calm water lacustrine environment.

- Our study in the Kilang Sarai paleodammed lake, located in the upper reaches of the Yunam river, reveals the widespread development of SSDS.

- Investigation of Yunam palaeolake sediments reveals evidence of four episodes (ca. 25.3, 20.1, 17.2 and $12.2 \mathrm{ka} \mathrm{BP}$ ) of activity during the period of lake existence. The damming of Yunam river to form Yunam lake deposits was caused by activation of NW trending normal fault which blocked the course of Yunam river around $25.3 \mathrm{ka}$ BP.

- This is the first direct evidence of chronologically constrained events of liquefaction features associated with the active faults from the upper Spiti (Tethys Himalaya).

- The SSDS represent the occurrence of earthquakes during the Late Pleistocene as manifestations of the ongoing regional tectonic processes.

\section{Acknowledgements}

The authors thank the two anonymous reviewers and the Editor, Dr R K Mangalampally, for their critical comments and constructive suggestions which greatly benefitted this paper. Dr Archna Bohra gratefully acknowledges Dr R Ramesh, PRL, Ahmedabad for his kind support during radiocarbon laboratory analysis.

\section{References}

Agrawal D P, Dodia R, Kotlia B S, Razdan H and Sahni A 1989 The Plio-Pleistocene geologic and climatic record of the Kashmir valley: A review and new data; Palaeogeogr. Palaeoclimatol. Palaeoecol. 73 267-286.

Allen C R 1975 Geological criteria for evaluating seismicity; Geol. Soc. Am. Bull. 86 1041-1057.

Allen J R L 1986 Earthquake magnitude-frequency, epicentral distance, and soft-sediment deformation in sedimentary basins; Sedim. Geol. 46(1-2) 67-75.

Allen J R L and Banks N L 1972 An interpretation and analysis of recumbent folded deformed cross bedding; Sedimentology 19 257-283.

Anoop A, Prasad S, Basavaiah N, Brauer A, Shahzad F and Deenadayalan K 2012 Tectonic versus climate influence on landscape evolution: A case study from the upper Spiti valley NW Himalaya; Geomorphology 145-146 32-44.

Banerjee D, Singhvi A K, Bagati T N and Mohindra R 1997 Luminescence chronology of seismites at Sumdo (Spiti Valley) near Kaurik-Chango Fault, northwestern Himalaya; Curr. Sci. 73(3) 276-281.
Bhargava O P 1990 Holocene tectonics south of the Indus suture, Lahaul-Ladakh Himalaya, India: A consequence of Indian plate motion; Tectonophys. 174 315-320.

Bhargava O N and Bassi U K 1998 Geology of Spiti-Kinnaur Himachal, Himalaya; Geol. Surv. India Memoir $\mathbf{1 2 4}$ $1-210$.

Bowman D, Korjenkov A and Porat N 2004 Late-Pleistocene seismites from Lake Issyk-Kul, the Tien Shan range, Kyrghyzstan; Sedim. Geol. 163 211-228.

Burbank D W and Johnson G D 1982 Intermontanebasin development in the past $4 \mathrm{Myr}$ in the north-west Himalaya; Nature 298 432-436.

Burgisser H M, Gansser A and Pika J 1982 Late glacial lake sediments of the Indus valley area, northwestern Himalaya; Eclogae Geol. Helv. 75(1) 51-63.

Campbell J A and Evan D J A 1990 Glaciotectonics and landsliding in little sand hill creek Alberta; Geomorphology 30 19-36.

Epard J L and Steck A 2004 The eastern prolongation of the Zanskar Shear Zone (western Himalaya); Eclogae Geol. Helv. 97 193-212.

Fort M, Burbank D W and Freytet P 1989 Lacustrine sedimentation in a semiarid Alpine setting: An example from Ladakh, northwestern Himalaya; Quat. Res. 31 332-350.

Greb S F and Dever G R 2002 Critical evaluation of possible seismites: Examples from the carboniferous of the Appalachian basin; In: Ancient Seismites (eds) Ettensohn F R, Rast N and Brett C E, Geol. Soc. Am. Spec. Paper 359 109-125.

Hibsch C, Alvarado A, Yepes H, Perez V H and Sebrier M 1997 Holocene liquefaction and softsediment deformation in Quito (Ecuador): A paleoseismic history recorded in lacustrine sediments; J. Geodyn. 24 259-280.

Hempton M R and Dewey J F 1983 Earthquake induced deformational structures in young lacustrine sediments, east Anatolian Fault, southeast Turkey; Tectonophys. 98 T7-T14.

Hintersberger E, Thiede R C, Strecker M R and Hacker B $2010 \mathrm{E}-\mathrm{W}$ extension in the northwestern Himalaya, NW India; GSA Bull. 122 1499-1515.

Jayangondaperumal R and Thakur V C 2008 Coseismic secondary surface fractures on southeastward extension of the rupture zone of the 2005 Kashmir earthquake; Tectonophys. 446 61-76.

Jayangondaperumal R, Mugnier J L and Thakur V C 2008 Earthquake slip estimation from the scarp geometry of Himalayan Frontal Thrust, western Himalaya: Implications for seismic hazard assessment; J. Earth Sci. 102 1937-1955.

Juyal N, Pant R K, Basavaiah N, Yadava M G, Saini N K and Singhvi A K 2004 Climate and seismicity in the higher central Himalaya during 20-10 ka: Evidence from the Garbayang basin, Uttaranchal, India; Palaeogeogr. Palaeoclimatol. Palaeoecol. 213 315-330.

Kelling G and Walton E K 1957 Load cast structures, their relationship to upper surface structures and their mode of formation; Geol. Mag. 94 481-490.

Ken-Tor R, Agnon A, Enzel Y, Stein M, Marcos S and Negendank J F 2001 High resolution geological record of historic earthquake in the Dead Sea Basin; J. Geophys. Res. 106 2221-2234.

Khatri K N, Rai K, Jain A K, Sinvhal H, Gaur V K and Mithal R S 1978 The Kinnaur earthquake, Himachal Pradesh, India of 19 January, 1975; Tectonophys. 49 $1-21$.

Kotlia B S and Rawat K S 2004 Soft sediment deformation structures in the Garbyang palaeolake: Evidence from the past shaking events in the Kumaun, Tethys Himalaya; Curr. Sci. 87(3) 377-379. 
Kotlia B S, Shukla U K, Bhalla M S, Mathur P D and Pant C C 1997a Quaternary fluvio-lacustrine deposits of Lamayuru basin, Ladakh Himalaya: Preliminary multidiciplinary investigations; Geol. Mag. 134(6) 807-812.

Kotlia B S, Bhalla M S, Sharma C, Ramesh R, Rajagopalan G, Mathur P D, Bhandari S and Chacko S T 1997b Palaeoclimatic conditions in the Upper Pleistocene and Holocene Bhimtal-Naukuchiatal lake basin in the southcentral Kumaun, North India; Palaeogeogr. Palaeoclimatol. Palaeoecol. 130 307-322.

Kotlia B S, Sanwal J, Phartiyal B, Joshi L M, Trevedi A and Sharma C 2010 Late Quaternary climatic changes in the eastern Kumaun Himalaya, India, as deduced from multi-proxy studies; Quat. Int. 213 44-55.

Kuenen P H 1958 Experiments in geology; Trans. Geol. Soc. Glasgow 23 1-28.

Kuenen P H and Menrad H W 1952 Turbidity currents, graded and nongraded bedding; Geology 58 91-127.

Marcos S, Stein M, Agnon A and Rond H 1996 Long-term earthquake clustering: A 50,000 years paleoseismic record in the Dead Sea; J. Geophys. Res. 101 6179-6192.

Mills P C 1983 Genesis and diagnostic value of soft sediment deformation structures a review; Sedim. Geol. 35 83-104.

Mohindra R and Bagati T N 1996 Seismically induced soft-sediment deformation structures (seismites) around Sumdo in the lower Spiti valley (Tethys Himalaya); Sedim. Geol. 101 69-83.

Mugnier J L, Huyghe P, Gajurel A P, Upreti B N and Jouanne F 2011 Seismites in the Kathmandu basin and seismic hazard in central Himalaya; Tectonophys. 509 33-49.

Obermeier S F 1996a Use of liquefaction-induced features for seismic analysis - An overview of how seismic liquefaction features can be distinguished from other features and how their regional distribution and properties of source sediment can be used to infer the location and strength of Holocene paleo-earthquakes; Eng. Geol. 44 1-76.

Obermeier S F 1996b Using liquefaction-induced features for paleoseismic analysis, Ch. 7, In: Paleoseismology (ed.) McCalpin, J P, San Diego, California, Academic Press, pp. 331-396.

Pant R K, Phadtare N R, Chamyal L S and Juyal N 2005 Quaternary deposits in Ladakh and Karakoram Himalaya: A treasure trove of the palaeoclimate records; Curr. Sci. 88(11) 1789-1798.

Perucca L P, Bracco A I and Moreiras S M 2009 Determination of seismogenic structures and earthquake magnitude from seismites in the Acequion river, Precordillera Range, central-western Argentina; J. Iberian Geol. 35(1) 5-18.

Phartiyal B and Sharma A 2009 Soft-sediment deformation structures in the Late Quaternary sediments of Ladakh: Evidence for multiple phases of seismic tremors in the northwestern Himalayan region; J. Asian Earth Sci. 34 $761-770$.

Phartiyal B, Sharma A, Srivastava P and Ray Y 2009a Chronology of relict lake deposits in the Spiti River, NW Trans Himalaya: Implications to Late PleistoceneHolocene climate-tectonic perturbations; Geomorphology 105(3-4) 264-272.

Phartiyal B, Srivastava P and Sharma A 2009b Tectonoclimatic signatures during late Quaternary period from Spiti valley, NW Himalaya, India; Him. Geol. 30(2) 164-174.

Postma G 1983 Water escape structures in the context of a depositional model of a mass flow dominated conglomeratic fan delta; Sedimentology 30 91-103.

Potter P E and Pettijohn F J 1963 Palaeocurrents and basin analysis; Springer, Berlin, 296p.

Rajendran K and Rajendran C P 2011 Revisiting the earthquake sources in the Himalaya: Perspectives on past seismicity; Tectonophys. 504 75-88.

Robyr M, Hacker B R Mattinson and James M 2006 Doming in compressional orogenic settings: New geochronological constraints from the NW Himalaya; Tectonics 25, doi: 10.1029/2004TC001774.

Rodríguez-Pascua M A, Calvo J P, De Vicente G and Gómez-Gras D 2000 Soft-sediment deformation structures interpreted as seismites in lacustrine sediments of the Prebetic Zone, SE Spain, and their potential use as indicators of earthquake magnitudes during the Late Miocene; Sedim. Geol. 135 117-135.

Rodríguez-López J P, Meléndez N, Soria A R, Liesa C L and Van Loon A J 2007 Lateral variability of ancient seismites related to differences in sedimentary facies (the synrift Escucha Formation, mid-Cretaceous, eastern Spain); Sedim. Geol. 201 461-484.

Rosseti D F 1999 Soft sediment deformation structures in late Albian to Cenomanian deposits, Sao Luis Basin, Northern Brazil: Evidence for palaeoseisimity; Sedimentology 46 1065-1081.

Sastry M V A, Chandra A and Mamgain V D 1970 Notes on Pleistocene varved clays and associated microfauna from Goting, Niti area of Kumaun Himalayas; Indian Minerals 24 131-133.

Sieh K E 1978 Prehistoric large earthquakes produced by slip on the SanAndreas Fault at Pallet Creek, California; J. Geophys. Res 83(B8) 3907-3939.

Sims J D 1973 Earthquake induced structures in sediments of Van Norman Lake, San Fenando, California; Science 182 161-163.

Sims J D 1975 Determining earthquake reccurrence intervals from deformational structures; Tectonophys. 29 141-152.

Singh S and Jain A K 2007 Liquefaction and fluidization of lacustrine deposits from Lahaul-Spiti and Ladakh Himalaya: Geological evidences of Palaeoseismicity along active fault zone; Sedim. Geol. 196 47-57.

Singh S, Sinha P, Jain A K, Singh V N and Srivastava L S 1975 Preliminary report on the January 19, 1975 Kinnaur Earthquake in Himachal Pradesh; Earthq. Eng. Struct. Dyn. 75 1-32.

Van Loon A J 2002 Soft sediment deformation in the Kleszczow Graben (Central Poland); Sedim. Geol. 147 57-70.

Visher G S and Cunningham R D 1981 Convolute laminations - a theoretical analysis: Example of a Pennsylvanian Sandstone; Sedim. Geol. 28 175-188.

Wang P, Zhang B, Qiu W and Wang J 2011 Soft-sediment deformation structures from the Diexi Palaeo-dammed lakes in the upper reaches of the Minjiang River, east Tibet; J. Asian Earth Sci. 40 865-872.

Yadava M G and Ramesh R 1999 Speleothems - Useful proxies for past monsoon rainfall; J. Sci. Indian Res. $\mathbf{5 8}$ 339-348. 